\title{
Keberlanjutan Sistem Usahatani Integrasi Tanaman-Ternak Pasca Bencana Alam Gempa Bumi di Daerah Istimewa Yogyakarta
}

\author{
N. Hidayat, Soeharsono dan S. Widodo \\ Balai Pengkajian Teknologi Pertanian Yogyakarta, \\ Jl. Rajawali No. 28 Demangan Baru, Yogyakarta, Fax. (0274) 562935
}

\begin{abstract}
ABSTRAK
Penelitian ini bertujuan untuk mengetahui dampak bencana alam gempa bumi terhadap keberlanjutan usaha integrasi tanaman - ternak sapi potong. Studi kasus dilakukan pada kelompok tani Bibit Mulyo Desa Tegaltirto, Kecamatan Berbah, Kabupaten Sleman Daerah Istimewa Yogyakjarta. Penelitian dilakukan pada bulan Juni - Juli 2006 dengan metode rapid livelihoods assesment dan focus group discussion. Data yang terhimpun, dianalisis dengan statistik deskriptif meliputi analisis frekuensi dan tabulasi silang. Hasil penelitian menunjukkan bahwa usahatani integrasi antara tanaman dengan ternak sapi potong dilokasi tersebut telah dilakukan sejak tahun 2003. Kondisi rumah tangga petani sekitar dua minggu pasca gempa di Daerah Istimewa Yogyakarta tidak memprioritaskan kegiatan sistem usahatani karena masih trauma dengan bencana gempa dan masih mengurus keluarganya yang luka dan rumahnya yang rusak. Akibat bencana gempa bumi 90 \% rumah(beserta isinya) milik petani hancur, kandang sapi mengalami kerusakan meliputi 8 kandang roboh , 12 unit rusak berat, 5 unit rusak sedang dan 5 unit rusak ringan serta 10 \% saluran irigasi juga mengalami kerusakan.Satu-satunya aset yang masih ada berupa lahan pertanian dan ternak sapi potong. Kematian ternak $0 \%$, namun $100 \%$ ternak mengalami stres sehingga nafsu makan turun. Pakan ternak tidak tersedia karena pasokan terlambat dan daya beli rendah sehingga pakan andalan hanya berupa jerami padi dan rumput lapang.. Dampak tersebut mengakibatkan penurunan produksi antara 20 - 30 \%. Diperkirakan 3 bulan pasca gempa bumi produksi ternak kembali normal. Sistem usahatani padi pada MK-1 terjadi keterlambatan panen dan kelangkaan pupuk sebagai akibat toko penyedia sarana produksi rusak dan ketersediaan terbatas sehingga terjadi keterlambatan pemupukan; namun hal ini dapat diatasi dengan optimalisasi penggunaan pupuk organik. Penurunan produksi padi pada MK-I diperkirakan $10-20 \%$. Sistem pola tanam palawija pada MK-2 tahun 2006 berjalan normal. Kesimpulan bahwa sistem integrasi usahatani tanaman-ternak menjadi strategi dalam membangkitkan kembali rumah tangga petani yang mengalami trauma akibat bencana alam gempa bumi.
\end{abstract}

Kata kunci : Pasca gempa bumi, integrasi tanaman-ternak sapi potong, pupuk organik

\section{The Economic Value of Farm System of the Integration Coffee Tree with Dairy Cow in Sleman Regency}

\section{ABSTRACT}

The research was done at the period of August 2001 until September 2002 with location in Jambu, Kepuharjo Village, Cangkringan Sub district, Sleman regency, Daerah Istemewa Yogyakarta province. The purpose of these research to detect the increasing production of Arabica Coffee tree and the economic value from the using faces and urine of dairy cow which have been proceeded being complex organic fertilizer. The research method use "on farm research" with 
involved farmer groups "Dadi Makmur" that has obtained arabica coffee tree since 1994 and care dairy cow with the property between 3-7 dairy cow/person. In those location has been occur the good integration between the arabica coffee trees with dairy cow livestock. In arabica coffe farm, the farmer use stale waste which in the form of faces and urine that has proceeded being organic fertilizer to fertilize their plantation in order to the producing coffee is called organic coffee. In this research is put complex organic fertilizer to arabica coffee tree in dosages $5 \mathrm{~kg} /$ tree, $10 \mathrm{~kg} / \mathrm{tree}$ and as a control is not put fertilizer. The research result indicate that the using fertilizer for $10 \mathrm{~kg} /$ tree has very real influence to the amount of unproduce coffee production with increasing product are $46,56 \%$ and give the economic value that is relative bigger when compared with using fertilize $5 \mathrm{~kg} /$ tree and without fertilize giving (control).

Key words : Economic value, integration of coffee tree-dairy cow, organic fertilizer

\section{PENDAHULUAN}

Pengembangan subsektor peternakan khususnya ternak sapi di Daerah Istimewa Yogyakarta secara regional memiliki makna yang strategis dan berperan penting dalam struktur perekonomian daerah guna menunjang persiapan otonomi daerah. Pengembangan peternakan berperan dalam meningkatkan fungsi ternak sebagai sumber penghasilan petani, penyerapan tenaga kerja, mengurangi impor daging dan meningkatkan ekspor daging, dan penghasil pupuk organik.

Usaha pengembangan ternak sapi di Daerah Istimewa Yogyakarta sebagian besar dilaksanakan oleh petani peternak kecil di Kabupaten Gunungkidul, Bantul, Kulonprogo dan Sleman. Pemeliharaan ternak tersebut dilakukan sebagai bagian usahatani dan dikelola sebagai usaha sampingan dengan modal yang terbatas, input rendah, skala usaha yang relatif kecil dan masih tergantung pada pakan lokal(Musofi, et al, 2000). Kondisi usaha ternak yang demikian ini merupakan kendala dalam menghadapi tantangan usaha peternakan untuk bersaing di pasar global, mengingat usaha yang bersifat subsisten tidak dapat menjamin suplai daging, susu, sapi bakalan secara kontinyu dengan harga yang bersaing.

Usaha integrasi tanaman-ternak telah umum dilakukan oleh petani peternak di wilayah DIY(Musofi, 2000). Integrasi antara ternak-tanaman akan mendatangkan berbagai keuntungan yaitu meningkatkan kualitas tanah dan produktivitasnya disebabkan adanya kotoran ternak serta menambah nilai tambah dari hijauan pakan ternak yang sebelumnya tidak dimanfaatkan(Edi Basuno, 1999). Wilayah perbukitan kritis di lereng gunung merapi merupakan wilayah berkembangnya sapi perah di Daerah Istimewa Yogyakarta. Produksi rata-rata sapi perah di daerah ini sangat rendah 3-8 liter/ekor/hari dengan cara pemeliharaannya yang belum memadai. Hal ini terjadi karena produksi yang rendah mengakibatkan peternak kurang berminat dalam memperbaiki managemen pemeliharaan sapi perahnya. Kesulitan hijauan terutama pada musim kemarau serta kondisi wilayah yang rawan erosi perlu mendapat perhatian. Potensi produksi sapi perah yang berkembang di wilayah ini masih dapat diperbaiki melalui perbaikan pakan, managemen pemeliharaan dan pengaturan reproduksi.

Perkembangan sapi perah di wilayah ini dapat mendorong petani dalam mengisi lahan kosong milik mereka untuk ditanami hijauan pakan ternak. Pembinaan yang berorientasi konservasi lahan melalui penataan penanaman hijauan pakan akan berdampak posistip terhadap peningkatan produksi hijauan pakan. Hal ini berati mendukung perbaikan pola pakan, penataan lahan yang benar serta berarti pula menekan laju erosi, sedangkan adanya ternak/sapi akan menambahkan sumber pupuk kandang identik dengan peningkatan kesuburan lahan sehingga memberikan peluang usaha dalam pengoptimalan diversifikasi pemanfaatan lahan. 
Usaha ternak memliki ketergantungan pada penyediaan sumber pakan ternak secara kontinyu (baik hijauan maupun konsentrat), terbatasnya lahan untuk pengembangan usaha, kesulitan pembuangan limbah berupa kotoran ternak dan permasalahan lingkungan sekitar usaha. Sedangkan usaha pertanian dan perkebunan menghadapi kendala dalam penyediaan sumber unsur hara untuk lahan, pertumbuhan tanaman yang kurang sehat akibat unsur hara yang berkurang, perawatan untuk peertum,buhan tanaman memerlukan biaya yang tidak sedikit dan permasalahan limbah yang semakin lama semakin menumpuk sehingga menjadi sarang hama dan penyakit kemudian menyerang buah yang siap panen. Kondisi tersebut dapat diatasi dengan melakukan integrasi antar sub sektor secara terpadu(Soeharto, 2000). Integrasi antara tanaman kopi dengan ternak sapi perah telah terjadi dengan baik dilereng Gunung Merapi. Kotoran ternak dimanfaatkan sebagai sumber pupuk organik yang sangat penting artinya dalam usahatani tanaman karena dapat memperbaiki produktivitas usahatani dan lingkungan melalui produksi pupuk kandang.

Tanaman kopi akan tumbuh dengan baik dan produksi tinggi apabila kebutuhan unsur haranya terpenuhi . Pupuk kandang sangat dibutuhkan bagi pertumbuhan tanaman,karena dapat meningkatkan kesuburan tanah,menambah unsur hara,memperbaiki struktur tanah dan kehidupan mikro organisme tanah (Setyamidjaya,1986). Usahatani kopi yang beintegrasi dengan usahaternak sapi perah akan menghemat biaya produksi, menyerap tenaga kerja yang lebih banyak dan sekaligus meningkatkan pendapatan petani. Tujuan pengkajian ini adalah untuk mengetahui peningkatan produktivitas tanaman kopi arabika dan nilai ekonomi dari penggunaan kotoran sapi perah(faeces dan urine) yang sudah diolah menjadi pupuk organik majemuk.

\section{MATERI DAN METODE}

Metode pengkajian yang digunakan adalah "on farm research" dengan melibatkan kelompok tani "Dadi Makmur" yang telah mengusahakan tanaman kopi arabika sejak tahun 1994 dan memelihara ternak sapi perah dengan kepemilikan ternak antara 3-7 ekor per orang. Di lokasi tersebut telah terjadi integrasi dengan baik antara tanaman kopi arabika dengan ternak sapi perah. Dalam usahatani kopi arabika petani menggunakan limbah kandang yang berupa kotoran sap(faces dan urine) yang telah diolah menjadi pupuk organik untuk memupuk tanaman mereka sehingga kopi yang dihasilkannya disebut kopi organik. Dalam pengkajian ini perlakuan yang diberikan berupa penggunaan pupuk organik majemuk pada tanaman kopi arabika dengan dosis $5 \mathrm{~kg} /$ pohon(A1), $10 \mathrm{~kg} /$ pohon(A2) dan sebagai kontrol tidak diberi pupuk (Ao). Rancangan percobaan faktorial digunakan sebagai pola percobaan. Untuk mengetahui nilai ekonomi dari usahatani integrasi antara sapi perah dengan tanaman kopi arabika mengunakan pendekatan analisa biaya dan pendapatan serta analisis $\mathrm{R} / \mathrm{C}$ ratio.

\section{HASIL DAN PEMBAHASAN}

\section{Keadaan umum daerah penelitian}

Dusun Jambu masuk wilayah Desa Kepuhardjo, Kec. Cangkringan , Kab. Sleman; terletak di kaki Gunung Merapi dengan ketinggian 700 meter dari permukaan laut. Lahannya merupakan lahan kering dan tanaman yang dominan adalah tanaman kopi. Luas lahan tanaman kopi 31,8 ha dan produksi kopi gelondong pada tahun 2000 sebesar 20,3 ton. Usaha ternak sapi perah telah cukup lama diusahakan petani di Dusun Jambu. Peternak sapi perah tergabung dalam satu kelompok tani "Dadi Makmur"; dengan jumlah anggota kelompok sebanyak 61 orang serta jumlah sapi perah yang dimiliki anggota kelompok sebanyak 216 ekor dengan produksi susu perhari berkisar antara 600 - 650 liter susu.

\section{Profil usaha integrasi ternak sapi perah dengan tanaman kopi}


Sub sektor peternakan sebagai bagian dari sektor pertanian dapat melakukan integrasi dengan sub sektor pertanian dan perkebunan untuk meningkatkan produktivitas masing-masing sub sektor. Ternak yang diusahakan dapat diintegrasikan dengan usaha pertanian dan perkebunan untuk saling mengisi masing-masing usaha dapat memberikan hasil yang optimal (Soeharto, 2000). Penggunaan limbah sebagai pupuk organik untuk tanaman kopi arabica mampu menekan biaya produksi dan meningkatkan produktivitas tanaman kopi.

Di Dusun Jambu telah terjadi integrasi dengan baik antara tanaman kopi arabika dengan usaha ternak sapi perah. Diagram alir integrasi antara ternak sapi perah dengan tanaman kopi arabica di Dusun Jambu disajikan pada Gambar 1. Dari gambar 1 dapat dijelaskan bahwa ternak sapi perah yang dikelola oleh petani/kelompok tani di Dusun Jambu dan diintegrasikan dengan tanaman kopi arabica; akan menghasilkan produk berupa susu dan kotoran sapi. Susu sapi tersebut oleh petani akan disetor ke koperasi susu dan kemudian susu dari koperasi tersebut akan ditampung oleh PT. Sari Husada.

Hasil samping dari beternak sapi yaitu kotoran sapi oleh petani/kelompok tani akan dibuat pupuk organik yang dipergunakan untuk memupuk tanaman kopi dan sisanya dijual. Tanaman kopi tersebut akan menghasilkan produk berupa biji kopi gelondong yang akan dijual /dipasarkan . Dari hasil penjualan susu, pupuk organik dan biji kopi tersebut petani akan menerima pendapatan yang kemudian dari pendapatan tersebut sebagaian akan dipergunakan untuk biaya hidup petani dan keluarganya dan sebagian lainnya untuk membeli saprodi; dimana saprodi tersebut oleh petani dipergunakan untuk mengelola usaha tani tanaman kopi maupun usaha ternak. Dengan demikian terjalin keterkaitan antara usahatani tanaman kopi dengan usaha ternak sapi perah yang akan meningkatkan produktivitas dan menghasilkan efisiensi dalam berusahatani.

\section{Nilai Ekonomi Penggunaan Pupuk Organik Majemuk pada Tanaman Kopi}

Analisis biaya, pendapatan dan nilai $\mathrm{R} / \mathrm{C}$ ratio dari penggunaan berbagai dosis pupuk organik pada tanaman kopi arabika disajikan pada tabel 1. 'Dari tabel 1 dapat dijelaskan bahwa untuk perlakuan Ao (tanpa pupuk organik) produksi kopi glondong yang dihasilkan.

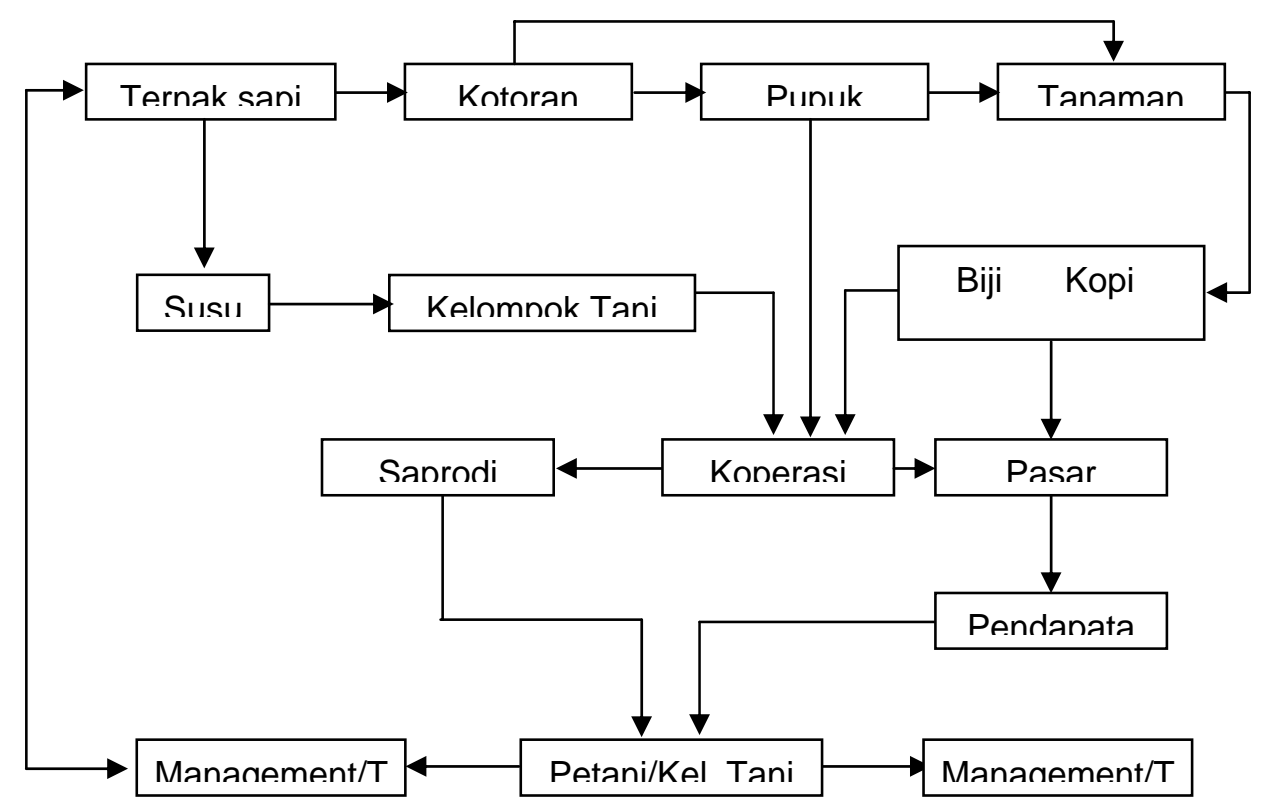


Gambar 1. Diagram alir integrasi antara ternak sapi perah dengan tanaman kopi arabika di Dusun Jambu, Desa Kepuharjo, Kec. Cangkringan Kab. Sleman.

Tabel 1. Analisis biaya, pendapatan dan Nilai R/C ratio dari usahatani kopiarabika di Dusun Jambu, Desa Kepuhardjo, tahun 2002

\begin{tabular}{lccc}
\hline \multirow{2}{*}{ Komponen } & \multicolumn{3}{c}{ Perlakuan } \\
\cline { 2 - 4 } & Ao & A1 & A2 \\
\hline Produksi kopi(kg/ha) & 2.380 & 2.660 & 4.454. \\
Penerimaan(Rp/ha) & 2.618 .000 & 6.650 .000 & 11.135 .000 \\
Biaya : & & & \\
a.Pupuk & - & 1.250 .000 & 2.500 .000 \\
b.Obat-obatan & 360.000 & 360.000 & 360.000 \\
c.Tenaga kerja & 600.000 & 600.000 & 600.000 \\
Total biaya & 1.260 .000 & 2.210 .000 & 3.460 .000 \\
Pendapatan & 1.358 .000 & 5.940 .000 & 7.675 .000 \\
R/C rasio & 2,07 & 3 & 3,22 \\
\hline
\end{tabular}

Sebesar $2.380 \mathrm{~kg}$ per hektar; dengan harga kopi gelondong Rp 1.100,- per kg maka akan diperoleh penerimaan kotor setahun sebesar Rp 2.618.000,-/ha. Total biaya yang diperlukan selama setahun sebesar Rp 1.260.000,-per ha sehingga dengan mengurangi total penerimaan kotor dengan total biaya yang dikeluarkan selama setahun maka dapat diperoleh pendapatan dari usahatani kopi arabika sebesar Rp 1.358.000,dengan nilai $\mathrm{R} / \mathrm{C}$ ratio 2,07.

Penggunaan pupuk organik majemuk pada tanaman kopi selain meningkatkan produktivitas tanaman kopi juga dapat meningkatkan kualitas biji kopi yang dihasilkannya; sehingga harga kopi yang dihasilkan dari proses organik harganya menjadi lebih tinggi. Pada perlakuan A1(dosis pupuk organik $5 \mathrm{~kg} /$ pohon) akan dihasilkan biji kopi gelondong selama satu tahun sebesar $2.660 \mathrm{~kg} / \mathrm{ha}$. Dengan harga Rp $2.500 / \mathrm{kg}$ maka dalam satu tahun akan diperoleh penerimaan kotor sebesar Rp 6.650.000,-/ha Total biaya yang dikeluarkan selama satu tahun sebesar Rp 2.210.000,-/ha, Dengan mengurangi total penerimaan kotor dengan total biaya yang dikeluarkan selama setahun maka pendapatan yang diperoleh selama setahun pada perlakuan A1 sebesar Rp 5.940.000,- dengan nilai $\mathrm{R} / \mathrm{C}$ ratio 3.

Pada perlakuan A2(dosis pupuk organik $10 \mathrm{~kg} /$ pohon) akan dihasilkan biji kopi gelondong selama satu tahun sebesar 4.454 kg/ha. Dengan harga Rp 2.500/kg maka dalam satu tahun akan diperoleh penerimaan kotor sebesar Rp 11.135.000,-/ha Total biaya yang dikeluarkan selama satu tahun sebesar Rp 3.460.000,-/ha, Dengan mengurangi total penerimaan kotor dengan total biaya yang dikeluarkan selama setahun maka pendapatan yang diperoleh selama setahun pada perlakuan A2 sebesar Rp 7.675.000,- dengan nilai $\mathrm{R} / \mathrm{C}$ ratio 3,22.

\section{KESIMPULAN}

Berdasarkan hasil pengkajian dapat disimpulkan bahwa penggunaan pupuk sebesar $10 \mathrm{~kg} /$ pohon sangat nyata pengaruhnya terhadap jumlah produksi kopi gelondong dengan kenaikan produksi sebesar 46,56 \% serta memberi nilai ekonomi yang relatif lebih besar bila dibandingkan dengan penggunaan pupuk 5 kg/pohon dan tanpa pemberian pupuk(kontrol). Pendapatan yang diperoleh selama setahun dari usahatani kopi arabika menggunakan pupuk organik dengan dosis $5 \mathrm{~kg} /$ pohon adalah sebesar Rp 5.940.000,-/ha dengan nilai R/C ratio 3 sedang pendapatan yang diperoleh selama setahun dari usahatani kopi arabika menggunakan pupuk organik dengan dosis 10 kg/pohon adalah sebesar Rp 7.675.000,-/ha dengan nilai $\mathrm{R} / \mathrm{C}$ ratio 3,22 . Pendapatan yang diperoleh selama setahun dari usahatani kopi 
arabika tanpa menggunakan pupuk organik sebesar Rp 1.358.000,-/ha dengan nilai R/C

\section{DAFTAR PUSTAKA}

Basuno, E dan Sabrani, 1999. Penelitian integrasi Ruminansia dan HTI di Pleihari, Kalimantan Selatan. Prosiding Seminar Nasional Peternakan dan Veteriner 1-2 Desember, 1998 di Bogor. Puslitbangnak Bogor.

Musofie, A 2000. Kontribusi pendapatan petani dari usaha pembesaran sapi potong dalam sistem usahatani integrasi tanamanternak. Prosiding seminar Teknologi Pertanian Untuk Mendukung Agribisnis Dalam Pengembangan Ekonomi Wilayah Dan Ketahanan Pangan. ratio 2,07

Nawawi, H. 1998. Metode Penelitian Sosial. Gadjah Mada Press. Yogyakarta

Puslitbang Peternakan, 2000. Program Pengkajian Sistem usahatani Tanaman Hewan. Proposal Inti. Puslitbang Peternakan Bogor

Soekartawi, Soehardjo, A, J.l. Dillon dan J.B. Hardaker. 1985. Ilmu usahatani dan Penelitian untuk Pengembangan Petani Kecil. Penerbit Univ. Indonesia Jakarta

Soeharto, 2000. Konsep pertanian terpadu mewujudkan keberhasilan dengan kemandirian. Makalah disampaikan sebagai bahan pelatihan " revitalisasi keterpaduan usaha ternak dalam sistem usahatani di Bogor dan Solo 21 Pebruari 6 Maret 2000. 